\title{
ANALISIS HUKUM KEDUDUKAN WALI HAKIM DALAM PELAKSANAAN PERKAWINAN
}

\author{
Rustam \\ Universitas Pohuwato \\ Email: mrustam37@yahoo.com
}

\begin{abstract}
Abstrak
Kedudukan wali hakim dalam pelaksanaan perkawinan hanya merupakan sebagai wali pengganti jika wali aqrab atau wali nasab tidak ada atau wali aqrab tidak mungkin menghadirkan karena jauh atau wali aqrab sedang ihram atau wali aqrab tidak diketahui keberadaannya atau wali aqrab enggan untuk menikahkan. Sepanjang wali aqrabnya ada dan tidak berhalangan maka wali hakim tidak mempunyai hak untuk melaksanakan perkawinan. Apabila perkawinan tetap dilaksanakan dengan menggunakan wali hakim namun wali aqrabnya masih ada dan wali aqrabnya tersebut tidak berhalangan maka perkawinan yang dilakukan itu adalah tidak sah/ batal.
\end{abstract}

Kata kunci: Wali, Kedudukan Wali Hakim, Perkawinan

\section{Abstract}

The position of magistrate guardian in the implementation of marriage is only as a surrogate guardian if either parental guardian also called Nazab guardian is absent, the place of parental guardian is far away, parental guardian is having Ihram, parental guardian is unknown, or parental guardian is reluctant to marry off. As long as there is parental guardian as well as he is not absent, the magistrate guardian does not have the right to carry out a marriage. if the marriage continues to be carried out using the magistrate guardian but there is parental guardian as well as he is not absent, the marriage which is carried out is illegal/void.

Keywords: Guardian, Guardian Position, Marriage

\section{A. Pendahuluan}

Manusia sejak dilahirkan di dunia sudah mempunyai kecenderungan untuk hidup bersama dengan manusia lainnya dalam suatu pergaulan hidup. Di dalam bentuknya yang terkecil, hidup bersama itu dimulai dengan adanya sebuah keluarga. Dimana dalam keluarga gejala kehidupan umat manusia akan terbentuk paling tidakoleh seorang laki-laki dan seorang perempuan. Hidup 
bersama antara seorang laki-laki dan seorang perempuan yang telah memenuhi persyaratan inilah yang disebut dengan perkawinan.

Manusia diciptakan Allah sebagai mahluk yang berpasang-pasangan dimana Setiap jenis membutuhkan pasangannya. Lelaki membutuhkan wanita dan sebaliknya wanita juga membutuhkan lelaki. Islam diturunkan oleh Allah untuk menata hubungan itu agar menghasilkan sesuatu yang positif bagi umat manusia dan tidak membiarkannya berjalan semaunya saja sehingga manjadi penyebab bencana.

Pernikahan merupakan ikatan yang amat suci, dimana dua insan yang berlainan jenis dapat hidup bersama dengan direstui Agama, kerabat, dan masyarakat dalam pandangan Islam. Dengan pernikahan ini berubahlah kekotoran menjadi kesucian, maksiat menjadi ibadah, dan dosa menjadi amal sholeh. Mereka memulai perjalanan berumah tangga yang panjang dengan saling cinta, tolong-menolong, dan toleransi. Al-Qur'an menggambarkan hubungan yang sah itu dengan suasana yang menyejukkan, akrab, mesra, kepedulian yang tinggi, saling percaya, pengertian dan penuh dengan kasih sayang.

Namun, dalam pelaksanaan pernikahan tersebut harus ada wali dari kedua belah pihak yang menikahkannya, terlebih-lebihnya wali dari pihak mempelai perempuan. Karena tidak sah pernikahan seseorang tanpa direstui/dinikahkan oleh wali, dan salah satu syarat pernikahan harus adanya wali, tanpa ada wali maka pernikahannya itu batal dan tidak diridhoi oleh Allah Subhana wata'alaa.

Wali adalah orang yang berhak atau berwenang untuk melakukan suatu perbuatan hukum bagi yang diwakilinya untuk kepentingan dan atas nama yang diwakili. Sedangkan wali dalam pernikahan adalah orang yang berhak menikahkan seorang perempuan yang diurusnya apabila wali sanggup bertindak sebagai wali. Apabila karena suatu hal ia tidak dapat bertindak sebagai wali maka hak kewaliannya berpindah kepada orang lain.

Begitu urgennya wali dalam pernikahan sehingga menjadi penentu sah atau tidaknya suatu pernikahan dalam Islam. Sebab pernikahan dapat dinyatakan sah apabila telah terpenuhi syarat-syarat dan rukun-rukun nikah yang telah ditentukan baik dalam hukum positif maupun hukum Islam. Dari sekian banyak syarat dan rukun nikah yang telah ditentukan dalam islam, wali nikah adalah salah satu hal yang sangat penting dan menentukan, bahkan menurut Imam Syafi'i tidak sah pernikahan tanpa adanya wali bagi pihak pengantin perempuan, sedangkan bagi calon pengantin laki-laki tidak 
diperlukan wali nikah untuk sahnya nikah tersebut. Sebagaiaman yang telah disabdakan oleh Rasulullah SAW, "barang siapa diantara perempuan yang menikah tidak dengan izin walinya, maka pernikanhhya batal." (Riwayat empat orang ahli hadits, kecuali nasai). Hadits lain, "tidak sah nikah kecuali dengan wali dan dua saksi yang adil" (Hadits riwayat Ahmad). ${ }^{1}$

Kedudukan wali sangat penting sebagaimana diketahui bahwa yang berhak menjadi wali nikah terhadap seorang wanita adalah hak bagi wali nasab apabila wali nasab tidak ada dan wali ghaib juga tidak ada maka perwalian pindah ke tangan wali hakim. Dalam hal seorang wanita tidak mempunyai wali sama sekali, para fuqoha telah sepakat tentang kebolehanya menggunakan wali hakim, tetapi hal perkawinan dengan wali hakim yang disebabkan oleh faktor yang lain, ternyata masih terdapat perbedaan pendapat.

Jika wali menolak untuk untuk menikahkan dengan alasan yang tidak tidak sesuai dengan ketentuan hukum syar'i (Hukum Islam) maka wali tersebut disebut wali adhal yaitu wali yang enggan menikahkan wanita yang telah baligh dan berakal sehat dengan seorang laki-laki pilihannya. Misalnya calon suaminya orang miskin, tidak tampan, tidak berpendidikan (sarjana) atau berasal dari suku yang berbeda. Maka hak perwaliannya dapat beralih/pindah kepada wali hakim, Sebab perbuatan wali yang tidak mau menikahkan wanita tanpa ada alasan syar'i adalah dilarang dan dianggap sebagai suatu tindakan yan zhalim kepada wanita. Hal tersebut diatas sesuai dengan Hadits Nabi Muhammad SAW:

"...jika mereka [wali] berselisih/bertengkar [tidak mau menikahkan], maka penguasa (as-sulthan) adalah wali bagi orang [perempuan] yang tidak punya wali."'(HR. Al-arba'ah).

Namun, lain halnya jika walinya tidak mau menikahkan dengan alasanalasan yang sesuai dan dibenarkan oleh hukum syar'i (hukum islam). Misalnya, calon suaminya berbeda agama, calon suaminya cacat sehingga tidak mampu melaksanakan kewajibannya sebagai suami atau calon suaminya fasiq (penjudi, pemabuk, pezina).

Akan tetapi, jika seorang wanita datang meminta untuk dinikahkan oleh wali hakim dengan menutup-nutupi keberadaan keluarganya, karena takut atau malu diketahui kelurganya dengan mengatakan keluarganya sudah tidak ada atau keluarganya sulit dihubungi padahal sesungguhnya tidak demikian. Sebagaimana kasus yang pernah terjadi pada tahun 2015 di Kabupaten

${ }^{1}$ Sulaiman Rasji, 2001, Fiqh Islam, Attahiriyah, Jakarta, hlm. 383. 
Pohuwato dimana seorang laki-laki menikah dengan seorang perempuan hanya dengan menggunakan wali hakim tanpa sepengetahuan orang tua selaku wali pihak mempelai perempuan. Jika terjadi demikian, bagaimana kedudukan wali hakim jika diperhadapkan dengan kasus seperti ini, dapatkah wali hakim menjadi wali wanita tersebut meskipun wali nazabnya masih ada, sementara wali nazabnya tidak mengetahui pelaksanaan perkawinan tersebut dan bagaimana status keabsahan perkawinannya ditinjau dari hukum islam maupun hukum positif.

Berdasarkan uraian latar belakang di atas maka penulis melakukan penelitian "Analisis Hukum Kedudukan Wali Hakim Dalam Pelaksanaan Perkawinan".

\section{B. Metode Penelitian}

Tipe penelitian yang digunakan dalam penulisan ini adalah penelitian Normatif. Penelitian ini dilaksanakan berdasarkan asas hukum dan peraturan hukum yang berlaku. Penelitian ini menitik beratkan pada pengkajian mengenai kedudukan wali hakim dalam pelaksanaan perkawinan, serta keabsahan perkawinan dengan menggunakan wali hakim ditinjau dari hukum Islam dan hukum positif.

\section{Hasil Penelitian dan Pembahasan}

\section{Kedudukan Wali Hakim dalam Pelaksanaan Perkawinan Menurut Hukum Islam dan Hukum Positif}

Pernikahan merupakan suatu perbuatan hukum, yang memerlukan syarat dan rukun agar dapat dipandang sah menurut hukum. Yang dimaksud syarat disini adalah syarat perkawinan, yaitu yang berkaitan dengan rukun-rukun perkawinan itu sendiri. Diantaranya syarat bagi mempelai pria yang bukan merupakan mahram dari mempelai wanita, atas kemauan sendiri, jelas orangnya dan tidak sedang menjalani ihram dan syarat bagi wanita diantaranya tidak berhalangan Syar'i, jelas orangnya dan tidak sedang menjalani ihram, adanya wali dan saksi. ${ }^{2}$

Keberadaan seorang wali dalam akad nikah adalah suatu yang mesti dan tidak sah akad perkawinan yang tidak dilakukan oleh wali. Wali nikah dalam perkawinan merupakan rukun yang harus dipenuhi bagi calon mempelai wanita yang bertindak untuk menikahkannya.

\section{hlm.30.}

${ }^{2}$ H.S.A Alhamdani (terj: Agus Salim) 1989, Risalah Nikah, Pustaka Amani, Jakarta, 
Apabila diperhatikan Hukum Islam tentang Perkawinan terdapat alasan - alasan yang kuat yang mengharuskan adanya wali dalam perkawinan. Karena itu dengan tegas mazhab Syafi'i mengharuskan adanya wali. Tanpa wali perkawinan itu tidak sah.

Para wali adalah mereka yang terdiri dari kerabat dekat calon mempelai perempuan disebut dengan wali nasab yang mempunyai wewenang/hak untuk mengawinkan calon mempelai perempuan sepanjang tidak terdapat hal-hal yang mengalihkan perwaliannya itu ke tangan wali hakim menurut hukum. Tidak ada perbedaan pendapat ulama mengenai bahwa sulthan boleh menjadi wali nikah. Kewenangannya menjadi wali nikah karena kedudukannya sebagai penguasa umum, sebagaimana kekuasaannya yang berkaitan dengan urusan harta kekayaan orang yang tidak mempunyai wali, demikian pula kekuasaanya yang berkaitan dengan pernikahan.

Dasar hukum yang menyatakan bahwa sulthan (penguasa umum) dapat menjadi wali dalam pernikahan adalah hadits Nabi Muhammad SAW yang diriwayatkan oleh Aisyah R.A:

"Artinya: perempuan mana saja apabila menikah dengan tidak seizin walinya, maka nikahnya batal. Dan jika (laki-laki yang menikahinya) menggaulinya, maka wajib baginya membayar mahar untuk kehormatan yang ia peroleh dari persebadanannya itu. Jika mereka (para wali) bertengkar, maka sulthan itu adalah wali bagi mereka yang tidak mempunyai wali". ${ }^{3}$

Sulthan disini adalah imam (pemimpin, kepala Negara) atau hakim atau yang ditugaskan untuk itu. Hadits diatas merupakan dalil bahwa ijab akad nikah tergantung pada walinya. Jadi, apabila wali melarang perempuan menikah yang berada dibawah perwaliannya, maka pernikahannya diserahkan kepada wali hakim. Demikian pula apabila tidak ada ditempat atau sedang ihram, atau calon mempelai sama sekali tidak mempunyai wali maka wali hakim boleh menikahkannya.

Undang - Undang Nomor 1 Tahun 1974 tentang Perkawinan tidak mengatur secara jelas ketentuan-ketentuan mengenai wali hakim. Namun demikian Kompilasi Hukum Islam (KHI) memberi rumusan mengenai wali hakim sebagaiman termaktub dalam pasal 1 huruf $b$ bahwa wali hakim adalah wali nikah yang ditunjuk oleh menteri agama atau pejabat yang

${ }^{3}$ Muhammad bin Ismail Alkahlani, Subulussalam, Bandung, 1976, hal.117 
ditunjuk olehnya, yang diberi hak dan kewenangan untuk bertindak sebagai wali nikah.

Dalam Peraturan Menteri Agama Republik Indonesia Nomor 2 Tahun 1987 tentang Wali Hakim menyatakan:

Pasal 1 huruf $b$, wali hakim adalah pejabat yang ditunjuk oleh menteri agama atau pejabat yang ditunjuk olehnya untuk bertindak sebagai wali nikah bagi calon mempelai wanita yang tidak mempunyai wali.

Pasal 2 ayat 1, bagi calon mempelai wanita yang akan menikah diwilayah Indonesia atau di luar negeri/wilayah ekstar-tertoria Indonesia ternyata tidak mempunyai wali nasab yang berhak atau wali nasabnya tidak memenuhi syarat atau mafqud atau berhalangan atau adhol maka nikahnya dapat dilangsungkan dengan wali hakim.

Melihat rumusan-rumusan wali hakim diatas dapat dipahami bahwa wali hakim memperoleh kewenangan atau berhak menjadi wali nikah berdasarkan jabatan yang ia pangku. Hal tersebut dapat dilihat dan dimaknai kata "pejabat" yang terdapat dalam rumusan Pasal 1 Huruf b di atas.

Kedudukan sebenarnya merupakan suatu wadah, yang isinya adalah merupakan hak-hak dan kewajiban tertentu. Hak dan kewajiban merupakan peranan, seseorang yang mempunyai kedudukan tertentu lazim disebut sebagai pemegang peranan. Hak merupakan wewenang untuk berbuat atau tidak berbuat sedangkan kewajiban adalah beban atau tugas. Jadi yang dimaksud dengan kedudukan wali disini adalah hak dan atau peranan yang dimiliki oleh wali dalam suatu perkawinan.

Dalam Undang - Undang Perkawinan mengadopsi mazhab Imam Syafi'i yang menyatakan bahwa wali nikah merupakan salah satu syarat sahnya suatu perkawinan. Hal tersebut memperjelas bahwa suatu perkawinan yang dilangsungkan tanpa wali menyebabkan tidak sahnya suatu perkawinan. Ketentuan ini dimuat secara implisit dalam Pasal 2 Ayat (1) Undang - Undang Nomor 1 Tahun 1974 tentang Perkawinan yaitu "Perkawinan adalah sah apabila dilakukan menurut hukum masing-masing agamanya dan kepercayaan itu."

Dengan demikian tidak ada perkawinan dalam Islam tanpa adanya wali sehingga perkawinan tersebut dianggap tidak sah menurut Hukum Islam. Sebab, dalam hukum islam wali merupakan rukun nikah, dimana keberadaannya merupakan bagian yang tak terpisahkan dengan pernikahan itu sendiri sehingga dengan ketiadaan wali itu sendiri, baik wali nasab 
maupun wali hakim, dapat menyebabkan perkawinan atau pernikahan itu dianggap tidak sah atau batal secara hukum Islam.

Dalam Hukum Islam, wali terbagi menjadi atas 3 (tiga) yaitu: wali nasab, wali hakim dan wali tahkim. Dari ketiga macam wali tersebut dapat dijelaskan sebagai berikut:

a. Wali Nasab ialah wali nikah yang hak perwaliannya didasari oleh adanya hubungan darah. Dijabarkan didalam pasal 21 Kompilasi Hukum Islam Wali nasab terdiri dari empat kelompok dalam urutan kedudukan, kelompok yang satu didahulukan dari kelompok yang lain sesuai erat tidaknya susunan kekerabatan dengan calon mempelai wanita.

1. Pertama, kelompok laki-laki garis lurus keatas yakni ayah, kakek dari pihak ayah dan seterusnya.

2. Kedua, kelompok kerabat saudara laki-laki kandung atau saudara laki-laki seayah, dan keturunan laki-laki mereka.

3. Ketiga, kelompok kerabat paman, yakni saudara laki-laki kandung ayah, saudara seayah dan keturunan laki-laki mereka.

4. Keempat, kelompok saudara laki-laki kandung kakek, saudara lakilaki seayah kakek dan keturunan laki-laki mereka.

b. wali nasab secara umum adalah orang yang terdekat dengan seorang perempuan, hal ini dapat dilihat pendapat Muhammad bin Ismail dalam kitabnya bahwa wali yaitu saudara yang terdekat dengan si perempuan tentang asbahnya bukan zawil arham atau orang yang berhak menikahkannya, karena suatu pernikahan tidak bias dilaksanakan tanpa ada walinya. ${ }^{4}$

c. Wali Hakim adalah wali nikah yang hak perwaliannya timbul karena orang tua perempuan menolak atau tidak ada, atau karena sebab lainnya. Dalam Kompilasi Hukum Islam pasal 23 dijelaskan bahwa Wali hakim baru dapat bertindak sebagai wali nikah apabila wali nasab tidak ada atau tidak mungkin menghadirinya atau tidak diketahui tempat tinggalnya atau gaib atau adhol atauenggan.Dalam hal wali adhol atau enggan maka wali hakim baru dapat bertindak sebagai wali nikah setelah ada putusan Pengadilan Agama tentang wali tersebut.

Sebab - Sebab Menggunakan Wali Hakim dalam suatu pernikahan yaitu sebagai berikut: 
a) Tidak adanya wali nasab

Bagi calon pengantin perempuan yang tidak mempunyai wali nasab seperti saudara baru tidak ada saudara yang memeluk Islam atau perempuan yang tidak mempunyai wali langsung mengikkut tertib wali atau anak luar nikah maka wali hakimlah yang menjadi wali dalam perkawinannya.

b) Anak tidak sah taraf atau anak angkat

Anak tidak sah taraf atau anak diluar nikah ialah anak yang lahir atau terbentuk sebelum diadakan perkawinan yang sah.

c) Wali yang ada tidak cukup syarat

Dalam Islam, jika wali aqrab tidak mempunyai cukup syarat untuk menjadi menjadi wali seperti gila, tidak sampai umur, dan sebagainya maka bidang kuasa wali itu berpindah kepada wali ab'ad mengikuti tertib wali. Sekiranya satu-satunya wali yang ada itu juga tidak cukup syarat tidak ada wali lagi yang lain maka bidang kuasa wali itu berpindah kepada wali hakim.

d) Wali aqrob menunaikan haji atau umroh

Dalam kitab minhaj tholibi dalam bab nikah menyatakan jika wali aqrob menunaikan haji atau umroh maka hak hak walinya terlucut dan hak wali itu juga tidak berpindahan kepada wali ab'ad tetapi hak wali itu berpindah kepada wali hakim.

e) Wali enggan

Para fuqoha sependapat bahwa bahwa wali tidak boleh enggan untuk menikahkan perempuan yang dalam kewaliannya tidak boleh menyakitinya atau melarangnya kawin dengan pilihan perempuan itu memenuhi kehendak syarat.

Penulis sepakat dengan apa yang telah disyaratkan dalam Kompilasi Hukum Islam yakni keharusan adanya wali nikah dalam pelaksanaan perkawinan. Demikian pula dengan undang-undang perkawinan mengakui pensyaratan keharusan adanya wali tersebut dalam perkawinan sebab, undang-undang perkawinan menganggap perkawinan adalah sah jika dilaksanakan menurut agama yang bersangkutan.

Dengan demikian, fungsi yang dimiliki oleh wali hakim baik berdasarkan Hukum Islam maupun Hukum Positif pada akhirnya adalah sama, yaitu sama-sama sebagai pengganti wali nasab atau wali aqrab yang tidak dapat melaksanakan tugasnya disebabkan oleh halangan dari pribadi masing-masing wali tersebut. Misalnya, Adhal (enggan menikahkan calon 
perempuan) atau di sebabkan oleh kondisi external yang melekat pada wali-wali itu seperti mafqud (tidak diketahui keberadaanya), sakit, wafat, jauh dari lokasi pernikahan, belum memenuhi syarat yang ditetapkan oleh hukum seperti gila, belum baligh, sebagaiamana yang terdapat dalam Undang-Undang Perkawinan atau pendapat mayoritas ulama yang mensyaratkan wali dalam suatu pernikahan.

\section{Keabsahan Perkawinan dengan Menggunakan Wali Hakim}

Menurut Hukum Islam, masalah batalnya suatu perkawinan disebabkan oleh karena kurang atau tidak sempurnanya salah satu syarat syarat dan rukun - rukun tertentu di dalam proses pelaksanaan perkawinan. Perkawinan sendiri harus memenuhi syarat dan rukun sahnya perkawinan, yang dimaksud dengan rukun perkawinan adalah hakekat dari perkawinan itu sendiri. Jadi, tanpa adanya salah satu rukun maka perkawinan tidak dapat dilaksanakan, namun apabila perkawinan itu telah dilaksanakan maka telah dianggap fasid atau batal. Menurut Pasal 14 Kompilasi Hukum Islam (KHI) disebutkan bahwa untuk melaksanakan perkawinan harus ada:
a. Calon suami
b. Calon istri
c. Wali nikah
d. Dua orang saksi dan
e. Ijab dan Kabul

Rukun dan syarat pernikahan menurut Ahmad Azhar basher adalah sebagai berikut:
a. Mempelai perempuan
b. Mempelai laki - laki
c. Wali
d. Dua orang saksi
e. Sighat (ijab dan Kabul)

Membahas mengenai keabsahan suatu perkawinan, dalam Pasal 2 Ayat (1) Undang -Undang Perkawinan secara implisit menyebutkan bahwa perkawinan adalah sah apabila dilaksanakan menurut masing-masing agamanya dan kepercayaannya itu. Artinya, bahwa Negara dalam hal ini tidak mau mencampuri persoalan sah/tidak sahnya suatu ibadah sehingga negara mengembalikan kepada ketentuan-ketentuan masing-masing agama mengenai keabsahan suatu ibadah (perkawinan), sebab dalam Islam itu 
sendiri perkawinan adalah merupakan suatu ibadah. Sebagaimana Firman Allah SWT dalam QS. Ar - Rūm/30:21: ${ }^{5}$

"Dan diantara tanda-tandanya, bahwa Dia menciptakan untuk kamu dari dirimu istri-istri, agar kamu menjadi tenang dengannya, dan menjadikan antara kamu kemesraan dan kasih sayang. Sungguh demikian menjadi tanda bagi kaum yang berfikir".

Jadi, dari ayat tersebut dapat dipahami bahwa tujuan perkawinan itu adalah untuk mendapatkan ketenangan dalam hidup, karena iklim dalam rumah tangga yang penuh kasih sayang dan mesra. Dan tentunya dilaksanakan dengan ketentuan dan syarat yang telah ditentukan dalam Islam.

Dengan pernikahan ini pula berubahlah kekotoran menjadi kesucian, maksiat menjadi ibadah, dan dosa menjadi amal sholeh. Tetapi dengan dilaksanakan pernikahan tersebut harus ada wali dari kedua belah pihak yang menikahkannya, terlebih-lebihnya wali dari pihak mempelai perempuan karena tidak sah pernikahan seseorang tanpa direstui/dinikahkan oleh wali, dan salah satu syarat pernikahan harus adanya wali. Tanpa ada wali, maka pernikahannya itu batal dan tidak diridhoi oleh Allah Subhana wata'alaa.

Keabsahan suatu perkawinan dengan berwalikan hakim dipandang sah oleh Hukum Positif dan Hukum Islam sepanjang perpindahan perwalian tersebut dilaksanakan berdasarkan ketentuan hukum yang berlaku. Sebagaimana sabda Nabi Muhammad SAW sebagai berikut:

"Perempuan mana saja apabila menikah tanpa seizin walinya maka nikahnya batal. Dan Jika (laki-laki yang menikahinya) menggaulinya, maka wajib baginya membayar mahar untuk kehormatan yang ia peroleh dari persebadanannya itu. Jika mereka (para wali) bertengkar, maka sultan itu adalah wali bagi mereka yang tidak mempunyai wali”.

Wali dalam suatu pernikahan merupakan rukun yang harus dipatuhi bagi calon mempelai wanita yang bertindak menikahkannya atau memberi izin pernikahannya. Namun, Wali dapat langsung melaksanakan akad nikah itu atau mewakilkannya kepada orang lain yang bertindak sebagai wali adalah seorang laki-laki yang memenuhi syarat hukum agama seperti Islam, balig, dan cakap.

${ }^{5}$ Op.cit. 
Pada dasarnya hak untuk menjadi wali dalam perkawinan ada di tangan wali aqrab/wali nasab, atau orang yang diberi wasiat untuk menjadi wali. Hanya wali aqrab saja yang berhak mengawinkan perempuan yang dalam perwaliannya dengan orang lain. Demikian pula dia berhak melarangnya kawin dengan seseorang apabila ada sebab yang dapat diterima, misalnya suami tidak sekufu atau karena si perempuan sudah dipinang orang lain lebih dulu, atau jelek akhlaknya, atau cacat badan yang menyebabkan perkawinannya dapat di fasakhkan. Dalam hal semacam ini wali aqrab adalah yang berhak menjadi wali dan haknya tidak dapat berpindah kepada orang lain, hingga kepada kalian sekalipun.

Menurut Imam Syafi'i wali merupakan salah satu dari empat hal yang menetapkan adanya pernikahan yaitu wali, kerelaan yang dinikahkan, kerelaan yang menikahi, dua saksi yang adil, serta yang kelima adalah mahar/maskawin. Sebagimana Syafi'iyyah, Malikiyyah dan Hanabilah sepakat dalam mensyaratkan adanya wali dalam keabsahan pernikahan, dan Hanafiyah berpendapat bahwa pensyaratan wali ini adalah untuk shoghiroh dan kabiroh majnunah sedangkan bagi balighah aqilah baik gadis ataupun janda berhak untuk menikahkan diri mereka selama sepadan / kufu, karena jika tidak sepadan maka wali berhak untuk mem-faskh nikahnya.

Para ulama berpendapat bahwa wali tidak boleh enggan menikahkan perempuan yang dalam perwaliannya, tidak boleh menyakitinya atau melarangnya kawin, padahal yang akan mengawininnya itu sudah sekufu dan sanggup membayar maskawin. Dalam hal seperti ini apabila walinya enggan menikahkan, maka si perempuan berhak mengadukan halnya kepada hakim untuk dinikahkan. Dalam hal semacam ini hak wali yang enggan menikahkan iti tidak berpindah kepada wali hakim yang lebih rendah tingkatannya, tetapi langsung berpindah ke tangan hakim.

Perpindahan perwalian harus melihat dari urutan prioritas, artinya prioritas pertama untuk menjadi wali nikah adalah mereka yang berada dalam kelompok wali nasab/wali aqrab. Namun demikian, bagaimana jika seorang wanita dinikahkan oleh wali hakim atau wali jauh $\left(a b^{\prime} a d\right)$ sementara wali aqrabnya masih ada para fuqaha berbeda pendapat tentang hal ini. ${ }^{6}$

\footnotetext{
${ }^{6}$ Ahmad Rofiq, 2000, Hukum Islam Indonesia, PT. Raja Grafindo Persada, Jakarta, hlm.83.
} 
Menurut Imam Syafi'i wali $a b$ 'ad tidak boleh mengawinkan perempuan selama masih ada wali aqrabnya yang memenuhi syarat untuk menjadi wali. Sementara, menurut mazhab Hanafi, jika wali ab'ad mengawinkan seorang perempuan padahal wali aqrabnya masih ada, maka perkawinan itu sah jika perkawinan itu disetujui oleh wali aqrabnya, kalau tidak disetujui maka perkawinan itu tidak sah.

Mazhab maliki berpendapat tertib antara wali-wali itu bukan merupakan syarat. Oleh karena wali $a b$ 'ad boleh mengawinkan perempuan walaupun wali aqrabnya masih ada. Misalnya saudara (aqrob) dan paman (ab'ad), lalu paman bertindak menjadi wali.

Menurut Ibnu Rusyd, silang pendapat ini disebabkan apakah urutan walai itu merupakan hukum syara', yaitu ditetapkan oleh syara' untuk urusan perwalian ataukah bukan merupakan hukum syara' lalu apakah wali itu merupakan hak wali dekat (aqrab) ataukah hak Allah. Dikalangan fuqahan yang tidak menganggap tertib urutan wali itu merupakan hukum syara' mereka berpendapat wali jauh (ab'ad) itu boleh mengawinkan walaupun ada wali aqrab. Sementara fuqaha yang menganggap bahwa wali itu merupakan tertib wali tersebut merupakan hukum syara', mereka mengatakan apabila wali aqrab membolehkan maka akad nikah sah dan boleh diteruskan. Akan tetapi, wali aqrab tidak membolehkan, maka perkwinan itu dibatalkan. Fuqaha yang berpandangan bahwa perwalian itu hak Allah maka perkawinan itu tidak terjadi.

Peneliti sendiri sependapat dengan pendapat Imam Syafi'I dan Imam Hanafi yakni wali jauh ( $\left.a b^{\prime} a d\right)$ tidak boleh menjadi wali nikah jika wali nasab atau wali aqrabnya masih ada. Berdasarkan pendapat imam Syafi'I dan Imam Hanafi diatas maka peneliti berpendapat bahwa wali hakim tidak dapat menjadi wali nikah sepanjang wali aqrabnya masih ada. Dan jika perkawinannya tetap dilansungkan dengan menggunakan wali hakim maka perkawinannya tidak sah atau batal. Kecuali wali aqrabnya setuju dengan pernikahan tersebut maka perkawinan tersebut sah dan dapat dilanjutkan.

Sebelumnya telah diterangkan bahwa wali anak perempuan merupakan hak dari wali aqrab yang tidak dapat berpindah kepada wali lain atau kepada penguasa, kecuali apabila ada sebab-sebab yang dapat diterima. Hal - hal yang menyebabkan hak menjadi wali dapat berpindah 
kepada wali hakim, yaitu Wali yang ditunjuk dengan kesepakatan kedua belah pihak (calon suami-istri) wali hakim itu harus hatus mempunyai pengetahuan sama dengan qadhi. Adapun perpindahan wali nasab kepada wali hakim dapat dijelaskan sebagai berikut:

a. Wali aqrab atau wali ab'ad tidak ada sama sekali.

b. Wali aqrab ada, tetapi akan menjadi calon mempelai pria, sedang wali aqrab yang sederajat (sama-sama anak paman) sudah tidak ada.

c. Wali aqrab ada, tetapi sedang ihram.

d. Wali aqrab ada tetapi tidak diketahui tempat tinggalnya (mafqud)

e. Wali aqrab ada tetapi menderita sakit pitam.

f. Wali aqrab ada tetapi menjalani hukuman yang tidak dapat dijumpai.

g. Wali aqrab ada tetapi bepergian jauh sejauh perjalanan yang membolehkan sholat qashar.

h. Wali aqrab ada tapi menolak untuk mengawinkannya (adlal).

i. Calon mempelai wanita menderita sakit gila, sedang wali mujbirnya ayah atau kakeknya) sudah tidak ada lagi.

Seluruh mazhab sepakat bahwa hakim yang adil berhak mengawinkan laki-laki dan perempuan gila manakala mereka tidak mempunyai wali yang terdekat, berdasar hadist Nabi SAW yakni "Penguasa adalah wali bagi orang yang tidak punya wali." Akan tetapi, bagi Imamiyah dan Syafi'i hakim tidak berhal mengawinkan anak gadis yang masih kecil, sedangkan Hanafi mengatakan bahwa hakim punya hak atas itu, tetapi aqad tersebut tidak mengikat, dan sudah si anak sudah baligh dia berhak menolaknya. Pendapat ini sesungguhnya kembali pada pendapat Syafi'i dan Imamiyah sebab dalam keadaan seperti itu sang hakim telah melakukan aqad fudhuli (tanpa izin). Sementara itu, Maliki mengatakan bahwa apabila tidak ada wali yang dekat, maka hakim berhak mengawinkan anak laki-laki dan perempuan kecil, orang gila laki-laki dan perempuan dengan orang yang se-kufu serta mengawinkan wanita dewasa dan waras dengan izin mereka.

Dengan demikian, menurut Penulis penggunaan wali hakim sebagai wali nikah dalam pelaksanaan perkawinan adalah sah sepanjang perpindahan perwalian terebut sesuai dengan ketentuan dalam hukum positif dan Hukum Islam. Namun, jika dalam pelaksanaan perkawinan pengantin perempuan menggunakan wali hakim sebagai wali nikah sementara wali nasabnya atau wali aqrabnya masih ada dan tidak mempunyai halangan sebagaimana yang telah disyariatkan maka 
perkawinan tersebut dinyatakan batal atau tidak sah. Kecuali wali aqrabnya menyetujuinya maka perkawinan tersebut adalah sah dan dapat dilanjutkan.

\section{Kesimpulan}

Berdasarkan uraian hasil penelitian dan pembahasan diatas maka dapat ditarik beberapa kesimpulan sebagai berikut:

1. Dalam pelaksanaan perkawinan keberadaan wali sangat diperlukan sebab menjadi salah satu rukun dan penentu sah tidaknya suatu perkawinan, wali dapat dibagi menjadi tiga (3) bagian yaitu wali nasab, wali hakim dan wali tahkim. Berdasarkan susunan perwalian tersebut maka wali hakim baru dapat bertindak sebagai wali nikah apabila wali nasab tidak ada atau tidak mungkin menghadirkannya atau tidak diketahui tempat tinggalnya atau walinya lagi sedang ihram atau walinya enggan untuk menikahkannya. Dengan demikian kedudukan wali hakim dalam pelaksanaan perkawinan hanya sebagai wali pengganti artinya, selama masih ada wali nasab maka wali hakim tidak mempunyai hak untuk menjadi wali nikah.

2. Perkawinan dengan menggunakan wali hakim adalah sah apabila calon mempelai wanita tidak mempunyai wali nasab atau wali nasab enggan atau wali nasab tidak diketahui tempat tinggalnya atau wali nasab sulit untuk dihadirkan dan ketentuan lainnya yang disyariatkan agama islam. Namun, apabila perkawinan dilangsungkan dengan menggunakan wali hakim akan tetapi wali nasabnya masih ada dan perkawinan dilangsungkan tanpa sepengetahuan/izin wali nasab maka perkawinan tersebut adalah tidak sah.

\section{DAFTAR PUSTAKA}

\section{Buku}

Alhamdani, H.S.A (terj. Drs.Agus Salim), 1989. Risalah Nikah, Pustaka Amani, Jakarta.

Alkahlani, Muhammad bin Ismail, 1976, Subulussalam, Bandung.

Asmin, 2000, Status Perkawinan Antar Agama Ditinjau dari Undang - Undang Nomor 1 Tahun 1974, PT Dian Rakyat, Jakarta.

Daly, Peunoh, 1988, Hukum Perkawinan Islam (Suatu Perbandingan dalam Kalangan Ahlus - Sunnah dan Negara - Negara Islam), Bulan Bintang, Jakarta.

Ramulyo, Moh. Idris, 2000, Hukum Perkawinan, Hukum Kewarisan, Hukum Acara

Peradilan Agama dan Zakat menurut Hukum Islam, Sinar Grafika, Jakarta. Ramulyo, Moh. Idris, 2002. Hukum Perkawinan Islam, Bumi Aksara, Jakarta. 
Rasjid, Suleman dan Sulaiman Rasji, 2001, Fiqh Islam, Attahiriyah, Jakarta.

Rofi, Ahmad, 2000, Hukum Islam Indonesia, PT Raja Grafindo Persada, Jakarta.

Soekanto, Soerjono, 2006, Pengantar Penelitian Hukum, UI Press, Jakarta.

Syafiruddin, Amir, 2006, Hukum Perkawinan Islam di Indonesia (Antara Fiqh Munakahat dan Undang - Undang Perkawinan), Kencana, Jakarta.

Yunus, Mahmud, 1981, Hukum Perkawinan dalam Islam, Hidakarya Agung, Jakarta.

Yunus, Mahmud, 1990, Hukum Perkawinan Indonesia, CV. Mandar Maju, Bandung.

\section{Peraturan Perundang - Undangan}

Undang - Undang Nomor 1 Tahun 1974 tentang Perkawinan.

Peraturan Menteri Agama Nomor 2 Tahun 1987 tentang Wali Hakim.

Intruksi Presiden Nomor 1 Tahun 1991 tentang Kompilasi Hukum Islam. 